\begin{tabular}{|c|c|c|}
\hline 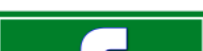 & Int.J.Curr.Microbiol.App.Sci (2021) 10(08): 219-233 & \\
\hline & $\begin{array}{l}\text { International Journal of Current Microbiology and Applied Sciences } \\
\text { ISSN: 2319-7706 Volume } \mathbf{1 0} \text { Number } 08 \mathbf{( 2 0 2 1 )} \\
\text { Journal homepage: } \underline{\text { http://www.ijcmas.com }}\end{array}$ & 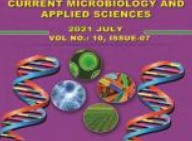 \\
\hline $\begin{array}{l}\text { EXCELLENT } \\
\text { PUBLISHERS }\end{array}$ & & \\
\hline
\end{tabular}

\title{
Tolerance Response of Sunflower (Helianthus annuus L.) Cultivar NSSH-1084 to Water Logging Stress
}

\author{
Debashree Dalai ${ }^{1}$ and Suchinnata Swapnasarita Sardar ${ }^{2 *}$
}

${ }^{1}$ Department of Botany, Utkal University, Vanivihar, Bhubaneswar-751004, Odisha, India

${ }^{2}$ Department of Botany, Ramadevi Women's Junior college, Bhubaneswar, Odisha, India

*Corresponding author

Keywords

Water logging stress, NSSH-1084,

MDA, proline, CAT, GPX

Article Info

\section{Accepted:}

15 July 2021

Available Online:

10 August 2021
Water logging remains a significant constraint to crop production across the globe. It affects plant growth, development and cause severe damage to plants from the early stage of growth. Sunflower is an oil seed cash crop favoured all over the world but the crop yield is influenced by water logging. The present study aims to evaluate the tolerance response of a sunflower (Helianthus annииs L.) cultivar NSSH-1084 to water logging stress. Here the effects of five water logging durations $(0,3,6,9,12$ days) were assessed during the early vegetative stage. The extent of influence on photosynthetic parameters, biochemical parameters and anti-oxidative enzymes, catalase (CAT) and Guaicol Peroxidase (GPX) were investigated during the water logging period. A decline in chl-a, chl-b and total chlorophyll was perceptible after 3 days of treatment. Sequential increase in soluble sugar and protein content was found insignificant for tolerance response above 3 days of treatment. Malondialdehde (MDA) and proline content enhanced for all the durations of water logging. A parallel increase in CAT and GPX activity was observed till 3 days of water logging. The outcome of the investigation indicates remarkable tolerance response of NSSH- 1084 up to duration of 3 days for water logging stress.

\section{Introduction}

Water logging remains a significant constraint to crop production across the globe in areas with high rainfall and poor drainage particularly in tropical and subtropical regions. Water logging is one of the focal abiotic stresses, which affects crop growth (1)(2)(3). It is also a matter of worldwide concern affecting $16 \%$ of the soils in the United States, $10 \%$ of the agricultural lands of Russia and irrigated crop production areas of India, Pakistan, Bangladesh, and China (4)(5). Water logging causes yield losses in various crops such as wheat, barley, canola, lupins, field peas (6)(7), lentils and chickpeas (8). Water logging impedes the ability of soil to provide an optimum medium for plant growth and 
alters its physical, chemical, electro-chemical and biological characteristics (9)(10)(11). Water logging hinders the growth of plants by reducing the dispersal of oxygen through the pore spaces in the soil around the root zone (12)(13)(14). Water logging decreases O2 diffusion capacity which leads to hypoxic or anoxic environments (15) (16).

Moreover, decreasing molecular oxygen prompts a sequence of changes in the physiochemical properties of the soil (17). Many of these also change soil chemical and electro chemicals by decreasing redox potential and excess electron changes (17)(18)(19). This brings about the imbalance in metal availability near root region and rise in solubility of some selected metals to toxic levels, which are potentially damaging to plant roots (20) (21) (22) (23). Even though the accumulation of phytotoxic compounds requires time, the absence of oxygen alone is enough to change the plant metabolic activities to critical levels (24) (25). So the change in physio-chemical properties, redox potential, $\mathrm{pH}$, level of toxicity of metals and oxygen deprivation impose a cascade of events to amplify abiotic stress upon the plants.

Under abiotic stress conditions, reactive oxygen species (ROS) levels are always elevated compared to pre-stress levels (26). Excessive production of various ROS such as superoxide radicals, hydroxyl radicals, hydrogen peroxide, and singlet oxygen found in hypoxia-stressed leaf and root tissues can also cause severe damage to plants (27) (28) (29) (30). All of these lead to restricted root growth, reduced tiller number, premature leaf senescence and production of sterile florets thus affecting the grain yield $(31)(32)(33)$.

When plants are subjected to environmental stresses, reactive oxygen species (ROS) are generated in response to stress conditions.
ROS can cause oxidative damage to many cellular components, including membrane lipids, proteins, nucleic acids, and chlorophyll. Some osmolytes namely proline (Pro), glycine betaine (GB), trehalose (Tre) are also expressed under environmental stress to get rid of the adverse condition (34). Plants also possess several anti-oxidant enzymes systems that protect their cells from negative effects of ROS. As water submergence stress occurs frequently and can affect most habitats, plants have developed several strategies to cope with these challenges. One of the stress defence mechanism is the antioxidant defence system, which includes antioxidants and antioxidant enzymes (35). These include ascorbate(AA), reduced glutathione(GSH) and enzymes including superoxide dismutase(SOD), peroxidise (POD), ascorbate peroxidise(APX), catalase (CAT). Moreever, ROS are inevitable by-products of normal cell metabolism (34). But under normal conditions productions and destruction of ROS is well regulated in cell metabolism (36). When a plant faces harsh conditions, ROS production will overcome scavenging systems and oxidative stress will burst. In these conditions, ROS attack vital bio molecules and disturb the cell metabolism and ultimately the cell causes its own death (37).

The effects of water logging on plants includes inhibition of growth of roots, shoots and new leaves and in turn causing decreased growth in the entire plant; reductions in the net photosynthetic rate, photosynthetic electron transport rate and photo-system II (PS II), photochemical efficiency (38)(39); reactive oxygen species (ROS) metabolism disorders (40), reductions in element uptake; and inhibition of transport from roots to leaves (41). However, a wide variety of plants are known for the tolerance to water stress and oxygen deficiency during the adult stages of their life cycle (42)(43). All plants have tolerance to water stress, but the extent varies from species to species (42). For example, 
flood sensitive plants like Lycopersicum esculentum, Glycine max, and Helianthus annuus show stunted growth and loss of yield potential in the waterlogged conditions, while plants like Oryza sativa can withstand waterlogging for a considerable time. However, continuous submergence of Oryza sativa is also deleterious resulting in death and decay of the plant. So cultivation of tolerant crop varieties can be considered as one of the solution for lands prone to water logging and optimum yield of the crop species.

Sunflower is a prominent cash crop favoured by most of the farmers worldwide. In india the cultivation of sunflower is on high demand as an oil yielding crop besides its other uses as cosmetics, biodiesel, agrichemicals, surfactants, adhesives, softeners, lubricants etc. Sunflower oil is a great source of linoleic acid, omega- 6 polyunsaturated fatty acid. It is favoured as one of the best industrial crop for its short duration, less demand for irrigation. It is mostly cultivated in agricultural land as a replacement to Rabi crops. But water logging in such lands has become the major obstacle for its optimum productivity reasoned by the erratic precipitation, irregular cyclonic depression and flood. So the aim of our objective is to examine the potential of a salt tolerant sunflower variety NSSH-1084 towards water logging and to study the different parameters of physiological and biochemical significance (44).

\section{Materials and Methods}

Seeds of sunflower (Helianthus annuus L.) of the variety NSSH-1084 were chosen for the study. The seeds were surface sterilised with $0.1 \% \mathrm{HgCl} 2$ for 2-3 minutes. Approximately 3-4 seeds were planted onto the cemented pot filled with $8 \mathrm{~kg}$ of soil in the ratio of soil: vermi-compost: sand(2:1:1/2). One healthy seedling out of 3 was allowed to grow after 10 days of germination. The selected seedlings were subjected to water logging treatment of different duration for 3 days, 6 days, 9 days and 12 days. One of the seedlings was treated normally with $500 \mathrm{ml}$ application of water. The total experimental design was carried out in pot culture. A single pot holds soil of $5 \mathrm{~kg}$. All the pots were saturated with water up to a height of $1 \mathrm{~cm}$ except control with a hole at the bottom of the pot for easy leak out of excess water. The whole experimental design was done in triplicate.

\section{Estimation of Chlorophyll}

The second leaf of the healthy plant of Helianthus annuus from the top was sampled for the experimental purpose. $0.1 \mathrm{~g}$ of leaf sample (finely cut leaf tissue) was grinded to fine pulp with addition of chilled $80 \%$ acetone. Absorbance was taken at $645 \mathrm{~nm}$ and $663 \mathrm{~nm}$ for chlorophyll estimation. Total chlorophyll content in the leaves was estimated as per Arnon, 1949 (45).

Chlorophyll $\mathrm{a}=((12.7 \times \mathrm{OD} \quad 663-2.69 \times \mathrm{OD}$ 645) $\times \mathrm{V} / \mathrm{FW} \times 1000)$

Chlorophyll $\mathrm{b}=((22.9 \times \mathrm{OD} \quad 645-4.68 \times \mathrm{OD}$ 663) $\times \mathrm{V} / \mathrm{FW} \times 1000)$

Total Chlorophyll $=((20.2 \times$ OD $645-8.02 \times$ OD 663) $\times \mathrm{V} / \mathrm{FW} \times 1000$ )

\section{Soluble Protein Estimation}

Soluble protein from healthy leaf was estimated using Bovine Serum Albumin (BSA) as standard as per Lowry method (46). The absorbance of each sample was recorded at $750 \mathrm{~nm}$ after $30 \mathrm{~min}$ incubation. The concentration of protein content was determined with reference to standard curve made by using standard BSA (Bovine Serum Albumin). Finally the absorbance of protein extract and BSA was recorded at $750 \mathrm{~nm}$. 


\section{Soluble Sugar Estimation}

Carbohydrate of leaf sample was estimated and the content of the sample was quantified by using a standard curve of glucose with OD at $620 \mathrm{~nm}$ as per Homme1992 (47).

\section{Proline Estimation}

Proline content of leaf estimated and further modified based on proline's reaction with ninhydrin as per Bates 1973(49). For proline colorimetric determinations, a 1:1:1 solution of proline, ninhydrin and glacial acetic acid was incubated at $100^{\circ} \mathrm{C}$ for 1 hour. The reaction was arrested in an iced bath and the cromophore was extracted with $4 \mathrm{ml}$ toluene and its absorbance was visualized $520 \mathrm{~nm}$.

\section{Lipid Peroxidation Estimation}

Lipid peroxidation was carried out as per the standard procedure by measuring the amount of Malonodialdehyde (MDA) generated due to thiobarbituric acid reaction as per Heath and Packer 1968 (48). Leaves were grounded with a pestle and mortar in 1\% TCA and centrifuged at 10,000 rpm for $5 \mathrm{~min}$. To $1.0 \mathrm{ml}$ of supernatant in a separate test tube, $4.0 \mathrm{ml}$ of 0.55 TBA was added followed by heating at $95 \mathrm{oC}$ for $30 \mathrm{~min}$ and cooling in ice-cold water with further centrifugation at 5,000 rpm for 5 min. Absorbance was measured at $532 \mathrm{~nm}$ and corrected for unspecific turbidity by subtracting the value at $600 \mathrm{~nm}$. The blank contained $1 \%$ TBA in 20\% TCA. MDA content was calculated using an extinction coefficient of $155 \mathrm{mM}-1 \mathrm{~cm}-1$ and the results expressed as $\mu \mathrm{mol} \mathrm{MDAg-1F.W.}$

\section{Antioxidant Enzyme Extraction and Assay}

Fresh leaves $(0.5 \mathrm{~g})$ of Helianthus annuиs $\mathrm{L}$. were homogenised with a mortar and pestle under chilled conditions with phosphate buffer $(0.1 \mathrm{M}, \mathrm{pH}$ 7.5) and EDTA $(0.5 \mathrm{~mm})$.The homogenate was centrifuged at $14,000 \mathrm{rpm}$ for
$10 \mathrm{~min}$ at $4^{\circ} \mathrm{C}$. The resulting supernatant was used for assay of different enzymes.

\section{Catalase (CAT)}

Catalase activity of control and stressed plants of Helianthus annuиs was estimated (50). About $3 \mathrm{ml}$ reaction mixture containing $1.5 \mathrm{ml}$ of $100 \mathrm{mM}$ potassium phosphate buffer $(\mathrm{pH}=7), 0.5 \mathrm{ml}$ of $75 \mathrm{mM} \mathrm{H} 2 \mathrm{O} 2,0.05 \mathrm{ml}$ enzyme extraction and distilled water to make up the volume to $3 \mathrm{ml}$. Reaction started by adding $\mathrm{H} 2 \mathrm{O} 2$ and decrease in absorbance recorded at $240 \mathrm{~nm}$ for $1 \mathrm{~min}$. Enzyme activity was computed by calculating the amount of $\mathrm{H} 2 \mathrm{O} 2$ decomposed.

\section{Guaiacol Peroxidase (GPX)}

GPX was assayed and the reaction mixture comprises of phosphate buffer $(\mathrm{pH}=6.0,50$ $\mathrm{mM}), \mathrm{H} 2 \mathrm{O} 2(10 \mathrm{mM})$, guaiacol $(2.25 \mathrm{mM})$ and $50 \mu \mathrm{l}$ of enzyme extract (51). The subsequent increase in absorbance of oxiguaiacol was measured at $470 \mathrm{~nm}$ and was defined as $\mu \mathrm{mol}$ of $\mathrm{H} 2 \mathrm{O} 2$ per min.

\section{Statistical Analysis}

All results are presented as the mean values \pm standard errors. The statistical significances of differences between mean values were assessed by analysis of variance and Duncan's multiple range tests. $\mathrm{P}<0.05$ was considered significant.

\section{Results and Discussion}

\section{Chlorophyll content (Chl-a, Chl-b and total Chlorophyll)}

Chl-a, Chl-b and total Chlorophyll content of leaf in mgg-1 FW were determined in plants subjected to different days of water logging at vegetative stage (Table-1).

During vegetative stage $\mathrm{Chl}$ a content 
increases significantly only up to 3 days of water logging as compared to control.

The content varied with a value of 1.0020 $\mathrm{mgg}^{-1} \mathrm{FW}$ at control to a highest value of $1.2620 \mathrm{mgg}^{-1} \mathrm{FW}$ at 3 days among the treatments but still higher $1.2091 \mathrm{mgg}^{-1} \mathrm{FW}$ at 6 days of treatment than the control.

The Chl a content decreases significantly at 9 days of water logging and continues up to 12 days of water logging with values of 0.7425 $\mathrm{mgg}^{-1} \mathrm{FW}$ and $0.6147 \mathrm{mgg}^{-1} \mathrm{FW}$ respectively. Chlorophyll a level was seen to be lower than the control plants when plants were subjected to both 9 days and 12 days of water logging. The trend shows a gradual decrease of chlorophyll content from control to 12 days of water logging treatment except at the 3 days of submergence.

Chl-b content of the leaf showed a similar trend like Chl-a. During vegetative stage the Concentration of $\mathrm{Chl} b$ showed a magnitude of $0.4017 \mathrm{mgg}^{-1} \mathrm{FW}$ at control and increased significantly higher to $0.4970 \mathrm{mgg}^{-1} \mathrm{FW}$ at 3 days of water logging. There onwards it showed a deceasing trend of $0.4333,0.3126$, $0.1837 \mathrm{mgg}^{-1} \mathrm{FW}$ at 6 days, 9 days \& 12 days of water logging respectively. The decreasing trend of $\mathrm{Chl} b$ from 9 days onwards indicated a lower level of $\mathrm{Chl} b$ than the control.

The total Chlorophyll content showed a similar trend that of Chl a and Chl b. During the vegetative stage the magnitude of total chlorophyll content was found to be 1.4098 , $1.8590,1.7428,1.0551,0.8984 \mathrm{mgg}^{-1} \mathrm{FW}$ at control, 3 days, 6 days, 9 days and 12 days of water logging respectively.

Following the trend shown by Chl-a \& Chl-b the total Chlorophyll level was seen to be lower both at 9 and 12 days of water logging than control plants.

\section{Protein Content}

Total protein content results were given in Figure-1. The result showed an increasing trend of protein content up to 9 days of water logging during the vegetative stage. There was an increase of protein concentration from control to 3 days, 6 days and 9 days recorded at a value of $5.8928,10.1785,12.8000$, $14.6640 \mu \mathrm{mol} \mathrm{g}^{-1} \mathrm{FW}$ respectively. However the protein content during vegetative stage of 12 days of water logged plants was seen to be $5.343 \mu \mathrm{mol} \mathrm{g}^{-1} \mathrm{FW}$ that stands at a value lower than the controlled plants at $5.898 \mu \mathrm{mol}$ $\mathrm{mg}^{-1} \mathrm{FW}$.

\section{Soluble Sugar Content}

An increase in carbohydrate content from control to 12 days of water logging was evident from the outcome (Figure-2). The control plants showed a value of $105.4 \mathrm{mg} / \mathrm{l}$ FW followed by $124.1 \mathrm{mg} / \mathrm{l} \mathrm{FW}$ at 3 days, $185.5 \mathrm{mg} / \mathrm{l} \mathrm{FW}$ at 6 days, $239.8 \mathrm{mg} / \mathrm{l} \mathrm{FW}$ at 9days and $242.7 \mathrm{mg} / \mathrm{l} \mathrm{FW}$ at 12 days of water submergent plants.

\section{Proline content}

Water logging induced increase in proline content was observed in the leaves of all plants subjected to water logging (Figure-4) ranging from 3 days to 12 days as compared to control. The results were found to be 0.0715 $\mu \mathrm{mol} / \mathrm{g} \mathrm{FW}, 0.0981 \mu \mathrm{mol} / \mathrm{g}$ FW, 0.2565 $\mu \mathrm{mol} / \mathrm{g} \mathrm{FW}, 0.4925 \mu \mathrm{mol} / \mathrm{g} \mathrm{FW}$ and 0.6927 $\mu \mathrm{mol} / \mathrm{g}$ FW during vegetative stage from control to 12 days of water treatment.

\section{Lipid peroxidation}

Lipid peroxidation was estimated in terms of malondialdehyde (MDA) content of treated plants for water logging stress. Water logging induced increase in lipid peroxidation as MDA content was found to be ascending (Figure-3) 
from control to 12 days treated plants at values of $0.6951 \mu \mathrm{mol} / \mathrm{g} \mathrm{FW}, 1.1842 \mu \mathrm{mol} / \mathrm{g} \mathrm{FW}$, $1.6217 \mu \mathrm{mol} / \mathrm{g} \mathrm{FW}, 2.3267 \mu \mathrm{mol} / \mathrm{g} \mathrm{FW}$ and $2.8322 \mu \mathrm{mol} / \mathrm{g}$ FW for control, 3days, 6days, 9days and 12 days water logged plants respectively under the vegetative stage of growth.

\section{Antioxidant Enzymes Activities}

The GPX and CAT activities were recorded for all the treated plants under different range of water logged conditions. An increase in catalase activity was found from control to 3 days of water logged condition after which it deteriorates for more days of water logging.

\section{Catalase Activity}

During vegetative stage the activity of catalase was found to be highest in 3 days water logged plants with a value of $1.494 \mathrm{U} \mathrm{mg}^{-1}$ protein FW and decreased from 6 days to 12 days at values of $0.951,0.724 \& 0.535 \mathrm{U} \mathrm{mg}^{-1}$ protein FW at 6 days, 9 days \& 12 days water logged conditions respectively than control with a value of $1.298 \mathrm{U}$ mg-1 protein (Figure5).

\section{Guaicol Peroxidase Activity}

The peroxidase activity in each treatment under different water logged conditions was evaluated statistically. A significant increase in GPX activity was seen to occur from control to 3 days water logged condition (Figure-6). But subsequent decrease was seen from 6 days to 12 days of water logging treatments. The range of peroxidase activity was recorded at values of $0.162,0.200,0.147$, $0.146,0.131 \mathrm{U} \mathrm{mg}^{-1}$ protein $\mathrm{FW}$ during vegetative period from control to 3 days, 6 days, 9 days and 12 days respectively. However the activity of GPX was found much lower than the activity of catalase for the respective level of water logging treatment.
Under natural conditions plants are frequently exposed to transient or permanent water logging. Flood drastically influences the soil physio-chemical properties of the soil. A deprivation of oxygen concentration particularly imparts hypoxic to anoxic condition, which in other hand influences plant growth, development and survival. One of the best characteristic of plant response to soil water logging is the metabolic transformation from aerobic respiration to anaerobic fermentation (52,53). Plants also show adaptations with regards to metabolic, physiological and morphological features. Our present study aims to establish a relationship among the photosynthetic parameters, adaptive molecules expressed during such stress and the activities of the anti oxidant enzymes namely catalase and peroxidise (GPX) during the vegetative stage of growth.

Starting with the preliminary focus towards the chlorophyll content, there has been seen a significant increase for chl-a, chl-b and total chlorophyll concentrations up to 3 days of water logging as compared to the control, whereas the concentrations decrease thereafter up to the last treatment of 12 days. However, all the photoshynthetic pigments stood at a higher value than the control till 6 days of water logging. Previous studies also found decline of photosynthetic pigments in several crop species eg tomato, mungbean, cucumber, maize, wheat etc when subjectd to water $\operatorname{logging}(54,55,56,57,58,59)$. The result of our experiment was in agreement with the above literature only after 3 days of treatment. But the time of application and the variety used for examining the abiotic stress is equally important for establishing any conclusion (60). Ozcubukcu and Ergun 2013 suggested the superior pigment content of a tolerant wheat cultivar Ducula-4 over a sensitive cultivar Dogankent for the similar degree of water logging stress and also found the significant improvement of the negative effects of the 
stress in former than later. The protein content of different duration of water logging was observed to increase during the vegetative stage. While many of the literature confirmed decline of protein content with increase of submergence stress, Ashraf and Mehmood (1990) reported that there was an increase in soluble protein in Brassica juncea and a significant increase in total amino acids in $B$. carinata. compared to control (61).

Carbohydrate content: During water submergence there is a considerable shift from aerobic to anaerobic respiration as an adaptive mechanism. Our present study of investigation showed an increase in soluble sugar content under varying water logging conditions. Due to shifting of energy metabolism from aerobic mode to anaerobic mode under hypoxia or anoxia the energy requirements of tissue is greatly restricted as very few ATPs are generated per molecule of glucose. A high level of anaerobic metabolism in hypoxic or anoxic roots is therefore very important to supply the energy charge high enough which can sustain metabolism in roots for the survival of plants (62). Thus maintaining adequate level of readily metabolizable sugar in hypoxic or anoxic roots is one of the adaptive mechanism to water logging or oxygen deficient environments $(63)(64)(65)(66)$. So a significant increase in root sugar level was established in many plants, mostly in adaptive plants.

Many of the authors has conformed decrease in content of carbohydrate or soluble sugar in vigna radiate, ragi and rice (66)(68), but Pravin and Karmoker (2013) reported an increase in reducing sugar level in root, stem and leaf of jute(67). Similarly three of the tolerant maize genotypes(CM 121, CM 122 and CM 132) showing better tolerance against the stress maintaining better soluble sugar and starch accumulation ability was reported by Baranwal \& Singh 2002(58). So the ascending soluble sugar content in our result supports the tolerance response to the stress for prolong period.

The content of proline had shown an increasing trend for varying water logging periods during the vegetative stage. The proline shows the same mechanism of defence as under other abiotic stresses. It acts as osmoticum during stress and prevents membranes disintegration and maintains membrane stability. A wide range of report has observed such outcome in sunflower, Brassica, wheat and jute (69)(70)(71)(67).

Lipid peroxidation measured as MDA content had shown an increasing value from control to 12 days of water logging. Hence the oxidative damage obviously has enhanced the rate of lipid peroxidation under this prolonged period of treatment and shown a higher magnitude of membrane disintegration. Arbona et al., 2008 while working on citrus reported that there exist a direct relationship stress sensitivity and accumulation of MDA(72).Water logging induced increase in MDA content in two hybrids of maize(DH605, ZD958)suggested an impact of water logging on membrane integrity and thus membrane deterioration (73).

Antioxidant activities: Exposure of plants to most adverse conditions like hypoxia or anoxia possess oxidative stress, which affects plant growth due to production of ROS such as superoxide radicals and $\mathrm{H} 2 \mathrm{O} 2$ (74).

The activity of catalase has shown a similar trend for all the respective treatments. The catalase activity increases up to the level of 3 days of water logging and then decreases onwards as compared to control. 
Table.1 Effect of water logging on chlorophyll content a, b \& total chlorophyll (mg/g FW) of leaf during vegetative stage

\begin{tabular}{|c|c|c|c|}
\hline Treatment & Chlorophyll content-a & Chlorophyll content-b & $\begin{array}{c}\text { Total chlorophyll } \\
\text { content }\end{array}$ \\
\hline Control & $1.0028 \pm 0.02$ & $0.4017 \pm 0.01$ & $1.4098 \pm 0.08$ \\
\hline 3 Days & $1.2620 \pm 0.04$ & $0.4970 \pm 0.04$ & $1.8590 \pm 0.01$ \\
\hline 6 Days & $1.2091 \pm 0.01$ & $0.4333 \pm 0.01$ & $1.7428 \pm 0.01$ \\
\hline 9 Days & $0.7425 \pm 0.08$ & $0.3126 \pm 0.07$ & $1.0551 \pm 0.03$ \\
\hline 12 Days & $0.6147 \pm 0.06$ & $0.1837 \pm 0.09$ & $0.8984 \pm 0.03$ \\
\hline
\end{tabular}

Fig.1 Effect of water logging on protein content ( $\mu \mathrm{mol} / \mathrm{g} \mathrm{FW})$ of leaf during vegetative stage.

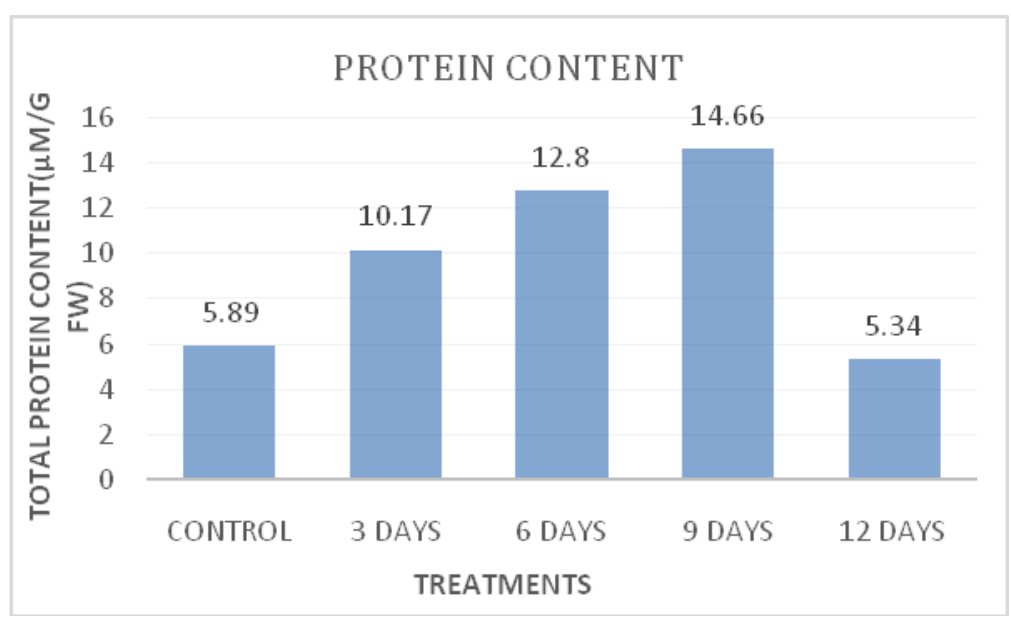

Fig.2 Effect of water logging on soluble sugar content (mg/l FW) of leaf during vegetative stage

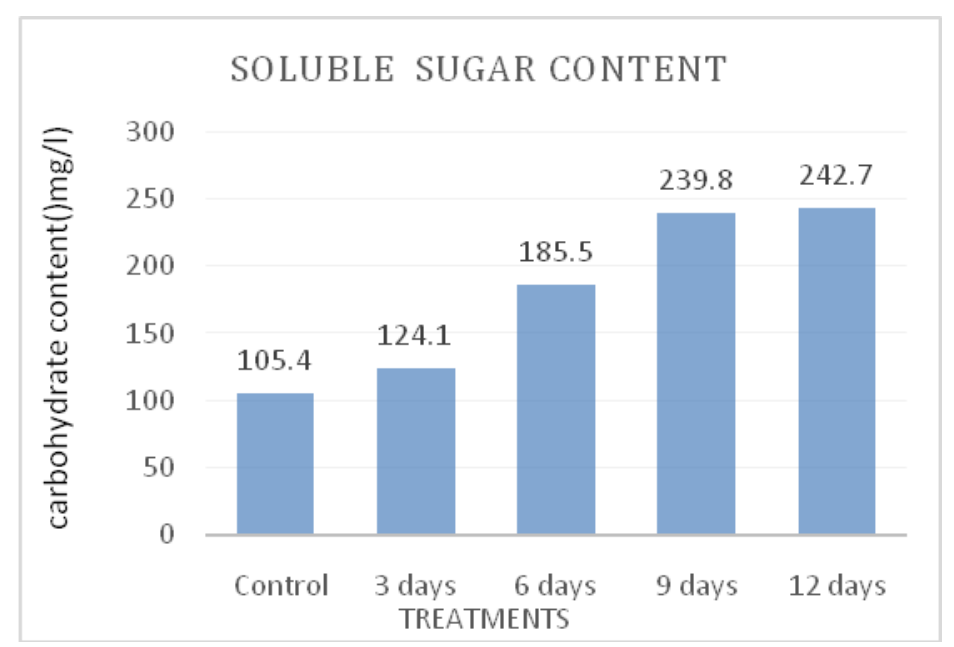


Fig.3 Effect of water logging on lipid peroxidation( $\mu$ mol MDA/g FW) of leaf during vegetative stage

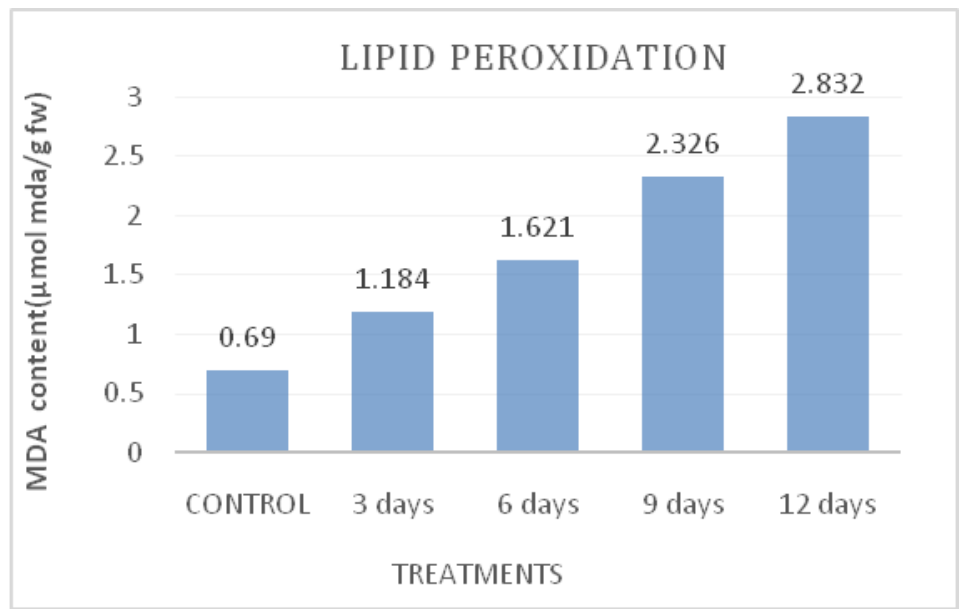

Fig.4 Effect of water logging on proline content ( $\mu$ mol proline/g FW) of leaf during vegetative stage

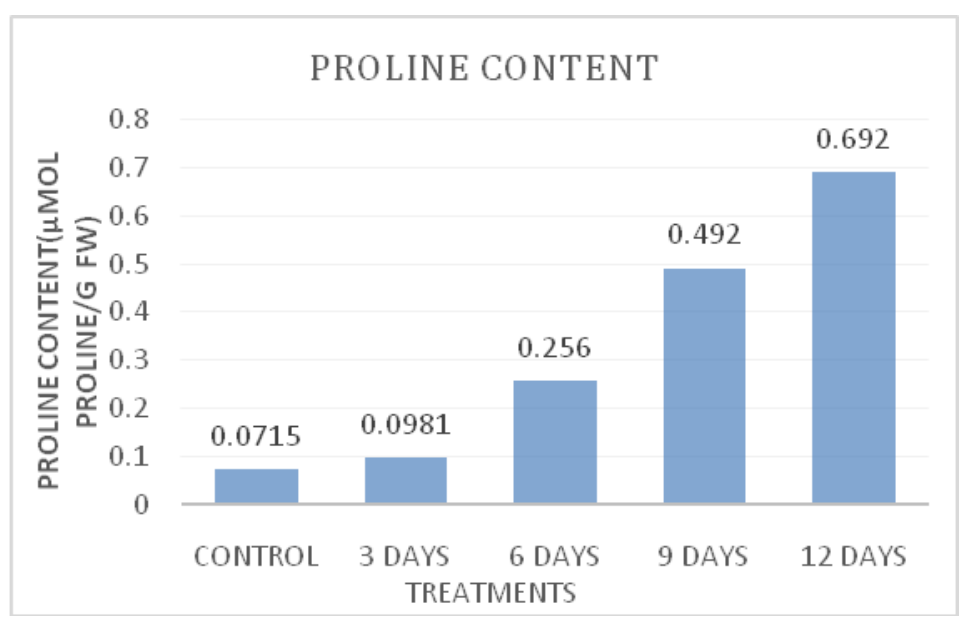

Fig.5 Effect of water logging on catalase activity (U/mg protein FW) of leaf during vegetative stage

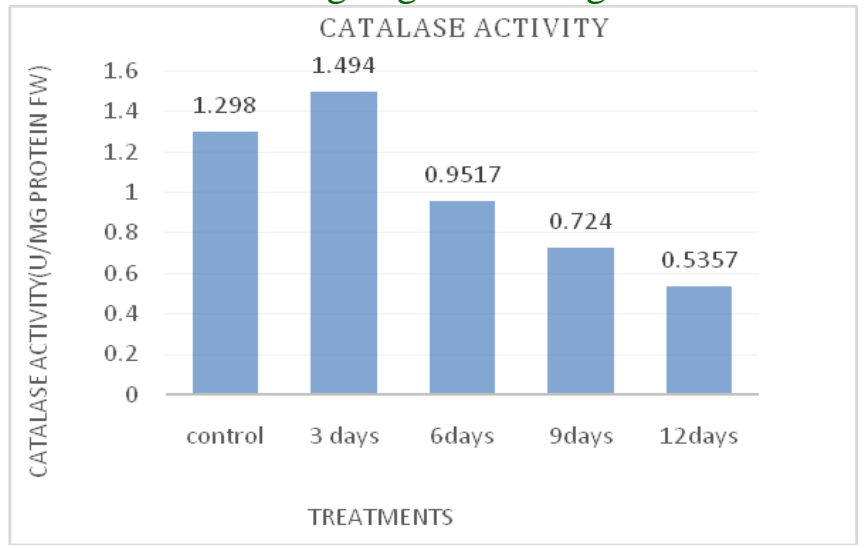


Fig.6 Effect of water logging on peroxidase activity(U/mg protein $\mathrm{FW}$ ) of leaf during vegetative stage

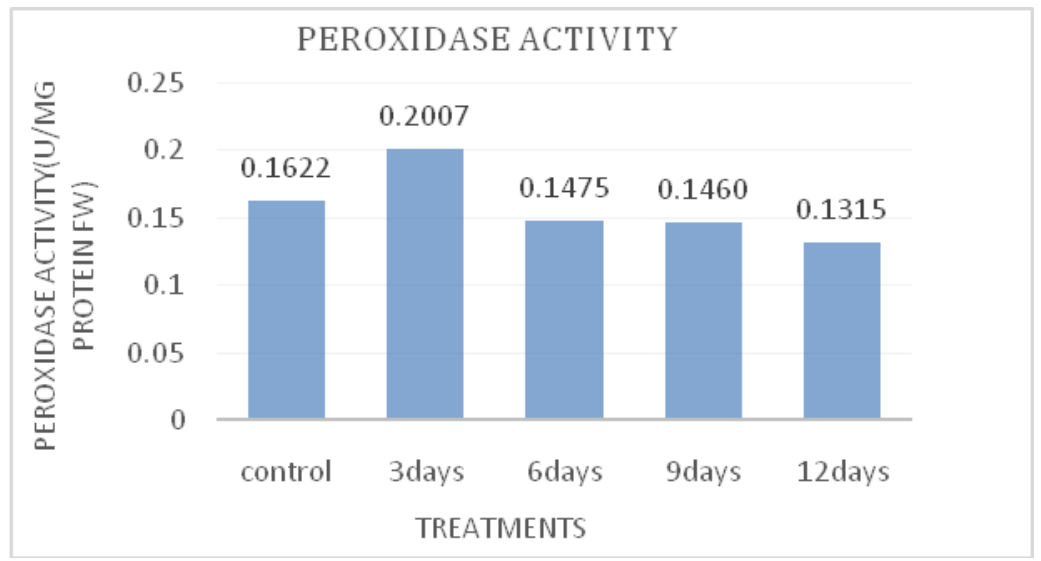

An exact similar activity has been shown by peroxidase enzyme. However, the activity of peroxidase was significantly lower than the activity of catalase at their respective treatments.

The decrease in activity of catalase (CAT) and ascorbate peroxidise(APX) was marked during water logging conditions in Mungbean by Ahmed et al., (57). APX served as a criteria for evaluating water logging in tomato and egg plant root (75). The varying degree of water logging stress generated oxidative stress and production of reactive oxygen species(ROS)and thus marked an increase in activities of enzymatic antioxidants in maize seedling (76)(77).Water logging for 72 hours lead to reduction in CAT, APX activity and reduction was more pronounced in susceptible genotype than in tolerant one in zea mays two tolerant variety (LMS,PRAKASH,) and three susceptibility variety (PMH2,JH-3459 and LM-14).

Moreover, the fact that the activities of catalase and peroxidise, the two $\mathrm{H} 2 \mathrm{O} 2$ scavenging enzymes, were above the control levels on the 3rd day signified their contribution to the antioxidant defence system. The present study, which was concerned with the effect of water logging stress, indicated that the activities of CAT and Gua-dep peroxidise (PODs) increased with the increase in the severity of the stress that withstand up to 3days and the parallelism among these enzymes themselves might provide partial protection, especially until the 3rd day of the treatment period.

In our study, the observed increases in the catalase(CAT) and Gu-dep peroxidise (GPX) activity of Helianthus annuus L. variety NSSH-1084 leaves till 3 days of water logging constituted the first line of defence via detoxification of free oxygen radicals. Additionally, similar changes were observed in both activities. However the activity of CAT is significantly higher than GPX for the respective duration of treatment.

The defence system was observed to stand strong till 3days of water logging as indicated by all the parameters studied, but failed to withstand prolonged submergence stress more than 3 days evident from the decline of photosynthetic pigments, escalation of lipid proxidation and reduction in antioxidant enzyme's activity.

The outcome suggests tolerance of the sunflower $(H$. annuus L.) variety NSSH-1084 towards water logging stress well up to 3 days. 
The tolerance response undergoes impairment of defence mechanism when subjected to prolonged period of water submergence.

\section{Acknowledgement}

The authors are thankful to the Department of Botany, College of Basic Science and Humanities, OUAT, Bhubaneswar, Odisha and P. G. Department of Botany, Utkal University, Vani Vihar, Bhubaneswar for providing infrastructural facilities to carry out the research. The research funding supported by DRS-III, University Grant Commission, New Delhi and FIST Department of Science and Technology, Govt. of India are highly acknowledged.

\section{References}

1. Linkemer G., Board, J. E., and Musgrave, M. E. (1998). Water logging effects on growth and yield components in lateplanted soybean. Crop Sci. 38, 15761584.doi:

10.2135/cropsci1998.0011183X003800060 $028 \mathrm{x}$

2. Setter T., and Waters I. (2003). Review of prospects for germplasm improvement for waterlogging tolerance in wheat, barley and oats. Plant Soil 253, 1-34.doi: 10.1023/A:1024573305997

3. Lone A. A., Khan M. H., Dar Z., A., and Wani, S. H. (2018). Breeding strategies for improving growth and yield under waterlogging conditions in maize: a review.Maydica 61:11.

4. Yaduvanshi N., Setter T., Sharma S., Singh K., and Kulshreshtha N. (2014). Influence of waterlogging on yield of wheat (Triticum aestivum), redoxpotentials, and concentrations of microelements in different soils in India and Australia. Soil Res. 50, 489-499. doi: 10.1071/SR11266

5. Food and Agriculture Organization (FAO) (2015). Food and Agriculture Organization of the United Nations. Available at: http://www.fao.org/3/abc600e.pdf
6. Bakker D., Hamilton G., Houlbrooke D., Spann C., and Van Burgel A.(2007). Productivity of crops grown on raised beds on duplex soils proneto waterlogging in Western Australia. Aust. J. Exp. Agric. 47, 1368-1376.doi: 10.1071/EA06273

7. Romina P., Abeledo L. G., and Miralles D. J. (2018). Physiological traits associated with reductions in grain number in wheat and barley under waterlogging. Plant Soil 429, 1-13.

8. Solaiman, Z., Colmer, T., Loss, S., Thomson, B., and Siddique, K. (2007). Growth responses of cool-season grain legumes to transient waterlogging. Aust. J. Agric.Res. 58, 406-412. doi: 10.1071/AR06330

9. Pulford, I., and Tabatabai, M. (1988). Effect of waterlogging on enzyme activities in soils. Soil Biol. Biochem. 20, 215-219. doi: 10.1016/0038-0717(88)90039-9

10. Glinski, J. (2018). Soil Physical Conditions and Plant Roots. Boca Raton, FL: CRC press. doi: 10.1201/9781351076708

11. Ferronato C., Marinari S., Francioso O., Bello D., Trasar-Cepeda C., and Antisari L. V. (2019). Effect of waterlogging on soil biochemical properties andorganic matter quality in different salt marsh systems. Geoderma 338, 302-312.doi: 10.1016/j.geoderma.2018.12.019

12. Drew, M., and Sisworo, E. (1977). Early effects of flooding on nitrogen deficiency and leaf chlorosis in barley. New Phytol. 79, 567-571. doi: 10.1111/j.14698137.1977.tb02241.x

13. Lee T. G., Jang C. S., Kim J. Y., Kim D. S., Park J. H., Kim, D. Y., et al., (2007). A Myb transcription factor (TaMyb1) from wheat roots is expressed during hypoxia: roles in response to the oxygen concentration in root environment and abiotic stresses. Physiol. Plant. 129, 375$385 . \quad$ doi: $\quad 10.1111 / \mathrm{j} .1399-$ 3054.2006.00828.x

14. Christianson J. A., Llewellyn D. J., Dennis E. S., and Wilson I. W. (2010). Comparisons of early transcriptome responses to low-oxygen environments in 
three dicotyledonous plant species. Plant Signal. Behav. 5, 1006-1009.doi: 10.1093/pcp/pcp163

15. Jaiswal A., and Srivastava J. (2018). Changes in reactive oxygen scavenging systems and protein profiles in maize roots in response to nitric oxide under waterlogging stress. Indian J. Biochem. Biophys. 55, 26-33.

16. Nguyen L. T., Osanai Y., Anderson I. C., Bange M. P., Tissue D. T., and Singh, B. K. (2018). Flooding and prolonged drought have differential legacy impacts on soil nitrogen cycling, microbial communities and plant productivity. Plant Soil 431, 371387. doi: 10.1007/s11104-018-3774-7

17. Ponnamperuma F. (1984). "Effects of flooding on soils," in Flooding and Plant Growth, ed. T. T. Kozlowski (Cambridge, MA: Academic Press), 9-45.doi: 10.1016/B978-0-12-424120-6.50007-9

18. Jackson, M., and Colmer, T. (2005). Response and adaptation by plants to flooding stress. Ann. Bot. 96, 501-505. doi: 10.1093/aob/mci205

19. Singh S. P., and Setter T. L. (2017). Effect of water logging on element concentrations, growth and yield of wheat varieties under farmer's sodicfield conditions. Proc. Natl. Acad. Sci. India Section B Biol. Sci. 87, 513-520.doi: 10.1007/s40011-015-0607-9

20. Jones H. E., and Etherington J. (1970). Comparative studies of plant growth and distribution in relation to waterlogging: I. The survival of Ericacinerea L. and E. tetralix L. and its apparent relationship to iron and manganese uptake in waterlogged soil. J. Ecol. 58, 487-496. doi: 10.2307/

a. 2258285

21. Aldana F., García P. N., and Fischer G. (2014). Effect of waterlogging stress on the growth, development and symptomatology of cape gooseberry (Physalis peruviana L.) plants. Rev. Acad. Colomb. Cienc. Exactas Fís. Nat. 38, 393-400.doi: 10.18257/raccefyn.114

22. Marash S. K. (2018). Evaluation of uptake rate and distribution of nutrient ions in wheat (Triticum aestivum L.) under waterlogging condition. Plant Physiol. 8,2539-2547

23. Sharma S. K., Kulshreshtha N., Kumar A., Yaduvanshi N. P. S., Singh M., Prasad K. R. K., et al., (2018). Waterlogging effects on elemental composition of wheat genotypes in sodic soils. J. Plant Nutr. 41, 1252-1262. doi: 10.1080/01904167.2018.1434541

24. Geigenberger P. (2003). Response of plant metabolism to too little oxygen. Curr.Opin. Plant Biol. 6, 247-256. doi: 10.1016/S13695266(03)00038-4

25. Perata P., Armstrong W., and Voesenek L. A. (2011). Plants and flooding stress.N. Phytol. 190, 269-273. doi: 10.1111/j.14698137.2011.03702.x

26. Miller G., Shulaev V., and Mittler R. (2008). Reactive oxygen signaling and abioticstress. Physiol. Plant. 133, 481-489. doi: 10.1111/j.1399-3054.2008.01090.x

27. Blokhina O., Virolainen E., and Fagerstedt K. V. (2003). Antioxidants, oxidative damage and oxygen deprivation stress: a review. Ann. Bot. 91, 179-194.doi: 10.1093/aob/mcf118

28. Sairam R., Kumutha D., Ezhilmathi K., Chinnusamy V., and Meena R.(2009). Waterlogging induced oxidative stress and antioxidant enzyme activities in pigeon pea. Biol. Plant. 53, 493-504. doi: 10.1007/s10535-009-0090-3

29. Petrov V., Hille J., Mueller-Roeber B., and Gechev T. S. (2015). ROS-mediated abiotic stress-induced programmed cell death in plants. Front. Plant Sci. 6:69.doi: 10.3389/fpls.2015.00069

30. Shabala S., White R. G., Djordjevic M. A., Ruan Y.-L., and Mathesius U.(2016). Rootto-shoot signalling: integration of diverse molecules, pathways and functions. Funct. Plant Biol. 43, 87-104. doi: 10.1071/FP15252

31. Collaku A., and Harrison S. (2005). Heritability of waterlogging tolerance in wheat. Crop Sci. 45, 722-727. doi: 10.2135/cropsci2005.0722

32. Hossain M. A., and Uddin S. N. (2011). Mechanisms of waterlogging tolerance in 
wheat: morphological and metabolic adaptations under hypoxia or anoxia.Aust. J. Crop Sci. 5, 1094-1101.

33. Cannarozzi G., Weichert A., Schnell M., Ruiz C., Bossard S., Blösch R., et al.,(2018). Waterlogging affects plant morphology and the expression of key genesin tef (Eragrostistef). Plant Direct 2:e00056. doi: 10.1002/pld3.56

34. Hasanuzzaman M., Bhuyan M. H. M., Zulfiqar F., Raza A., Mohsin S. M., Mahmud J. A., Fujita M and Fotopoulos V.(2020). Reactive Oxygen Species and Antioxidant Defense in Plants under Abiotic Stress: Revisiting the Crucial Role of a Universal Defense Regulator: Antioxidants.9, doi:10.3390/antiox9080681

35. Arbona V., Hossain Z., López-Climent M. F., Pérez-Clemente R. M., and GómezCadenas A. (2008). Antioxidant enzymatic activity is linked to waterlogging stress tolerance in citrus. Physiol. Plant. 132, 452-466. doi: 10.1111/j.13993054.2007.01029.x

36. Mittler R. (2002). Oxidative stress, antioxidants and stress tolerance: Trends Plant Sci. 7(9):405-10. doi: 10.1016/s13601385(02)02312-9.

37. Sakihama Y., Cohen M. F., Grace S. C., Yamasaki H.(2002). Plant phenolic antioxidant and prooxidant activities: phenolics-induced oxidative damage mediated by metals in plants; Toxicology 177,67-80

38. Yi Y. H., Fan D. Y., Xie Z. Q. and Chen F. Q. (2006). Effect of water logging on the gas exchange, chlorophyll fluorescence and water potential of Quercusvariabilis and Pterocaryasternoptera. $J$ plant Ecol(Chinese version)30:960-968

39. Liu Z., Cheng R., Xiao W., Guo Q. and Wang N (2014).Effect of Off-Season Flooding on Growth, Photosynthesis, Carbohydrate Partitioning and Nutrient Uptake in DistyliumChinese. PLoS ONE 9 (9): e107636.doi:10.1371/journal.pone.0107636 40. Lima A. L. S., Da Matta F. M., Pinheiro H.
A., Totola M. R. and Loureiro M. E. (2002). Photochemical responses andoxidative stress inn two clones of coffeasanephora under water deficit conditions. Environ Exp Bot 47:239-247.

41. Smethurst C. F., Garnett T. and Shabala S. (2005). Nutritional and chlorophyll fluorescence responses of lecerne(Medicago saliva) to waterlogging and subsequent recovery, Plant Soil 270:3145.

42. Vinocur D. and Wang G. D. (2003). Summary on plant physiological response to drought. Journal of plant growth research, 28(1): 10-22Senthil, L. (2012). Plant water stress. Journal of California plant Science, 2(4): 30-35.

43. Jackson A. (2003). A summary on water logging as a plant water stress. Journal of Australian Ecological Studies, 2(1):6-8.

44. Dalai D., Sardar S. S., and Pradhan C.(2019). NaCl Induced Oxidative Stress on Two Different Cultivars of Sunflower (Helianthus annuus L.) Int.J.Curr.Microbiol.App.Sci 8(8): 26072619

45. Arnon D I. Copper enzymes in isolated chloroplasts polyphenoloxidase in Beta vulgaris. Plant Physiol 4: 1-15, 1949.

46. Lowry O H, Roebrough N J, Randall R J and Farr A I. Protein measurement with folin phenol reagent.Biol. Chem., 193(1951) 265-275

47. Homme P M, Gonalez B and Billard J. Carbohydrate content, fructan and sucrose enzyme activities in roots, stubble and leaves of rye grass (Loliumperenne L.) as affected by source sink modification after cutting. Journal of Plant Physiology. 140 (1992) 283-291.

48. Heath R L and Packer L. Photoperoxidation in isolated chloroplasts I. Kinetics and stoichiometry of fatty acid peroxidation. Arch. Biochem. Biophys. 12 (1968)89-198.

49. Bates L S, Waldren R P, Teare I D. Rapid determination of free proline for waterstress studies. Plant Soil 39: 205-207, 1973.

50. Bergmeyer M. Methoden der enzymatischen Analyse, Vol. 1. AkademieVerlag. Berlin; 1970: pp. 636- 
647.

51. Scebba F, Sebastiani L, Vitagliano C. Activities of antioxidant enzymes during senescence of Prunusarmeniaca leaves. BiolPlantarum 44: 41-46, 2001

52. Dat J F, Breussegem V F, Vondenabele S, Vranova E, Montagu V M, Inze D (2000) Dual action of active oxygen species during plant stress responses. Cell Mol Life Sci 57:779-795

53. Dat J F, Capelli N, Folzer H, Bourgeade P, Badot PM (2004) Sensing and signalling during plant flooding. Plant PhysiolBiochem 42:273-282

54. Iqbal M., Raseed R., Ashraf M. A., Hussain I., Shafiq F., Yousaf A., AND Zaheer A.(2018). Glycine betaine counteracts the inhibitory effects of water logging on growth, photosynthetic pigments, oxidative defence system, nutrient composition and fruit quality in tomato. The joural of Horiculture Science and Biotechnology., 93(4):385-391

55. Ahmed S, Nawata E, Hosokawa M, Domae Y, Sakuratani T (2002). Alterations in photosynthesis and some antioxidant enzymatic activities of mungbean subjected to waterlogging. Plant Sci., 163:117-123

56. Barickman T. C., Simpson C. R., and Sams C. E.(2019). Waterlogging Causes Early Modification in the Physiological Performance, Carotenoids, Chlorophylls, Proline, and Soluble Sugars of Cucumber. 8, 160; doi:10.3390/plants8060160

57. Ahmed S., Nawata E., and Sakuratani T.(2002). Effect of water logging at reproductive and vegetative growth stages on photosynthesis, leaf water potential and yield in mungbean. Plant prod.Science. 5(2);117-123

58. Baranwal S., and Singh B. B.(2002): Effect Of Waterlogging On Growth, Chlorophylls and Saccharides Content In Maize Genotypes: Indian J. Plant Physiol., 7(3): 246-251

59. Olgun M., Kumlay1 A. M., Adiguzel M. C., and Caglar A.(2008). The effect of waterlogging in wheat ( $T$. aestivum L.). Acta Agriculturae Scandinavica Section B
Soil and Plant Science, 58: 193-198

60. Ozcubukcu S., and Ergun N.(2013). Effects of waterlogging and nitric oxide on chlorophyll and carotenoid pigments of wheat Journal of Food, Agriculture and Environment. 11(3,4): 2319-2323.

61. Ashraf M., and Mehmood S.(1990). Effects of water logging on growth and some physiological parameters of four Brassica species. Plant and Soil, 121:203-209

62. Jackson M B, Drew M C (1984) Effect of flooding on growth and metabolism of herbaceous plants. In: T T Kozlowski (ed) Flooding and plant growth. Academic Press, Orlando, 47-128

63. Setter T. L., Kupkanchanakul T., Kupkanchanakul K., Bhekasut P., Wiengweera A., Greenway H.(1987). Concentrations of $\mathrm{CO}_{2}$ and $\mathrm{O}_{2}$ in floodwater and internodal lacunae of floating rice growing at 1-2 metre water depths.-Plant Cell Environ. 10: 767-776

64. Jerry B. H. and Johnson W.(1995). Root Respiration and Carbohydrate Status of Two Wheat Genotypes in Response to Hypoxia. Annals of BotanyVolume.75 (4): 427-432.

65. Xia J H and Saglio P H (1992). Lactic acid efflux as a mechanism of hypoxic acclimation of maize root tips to anoxia. Plant Physiology 100: $40 \quad-46$. 10.1104/pp.100.1.40

66. Sairam R K, Kumutha D, Ezhilmathi K. (2009). Waterlogging tolerance: nonsymbiotic haemoglobin-nitric oxide homeostasis and antioxidants. Current Science 96 :674-682

67. Parvin D and Karmoker J L(2013): Effects Of Waterlogging On Ion Accumulation And Sugar, Protein And Proline Contents In Corchorus capsularis L. Bangladesh J. Bot. 42(1): 55-63

68. Kulkarni S. S and Chavan P. D.(2013). Influence of water logging on carbohydrate metabolism in Ragi and Rice Roots. Journal of stress physiology and Biochemistry, 9:199-205

69. Unal E., Unyayar S., and Kelep Y.(2004). Proline and ABA levels in two sunflower 
genotypes subjected to water stress. Bulg J. Plant Physiology 30(3-4):34-47

70. Flasinski, S., and Rogozinska, J. (1985). Effect of water deficit on proline accumulation, protein and chlorophyll content during flowering and seed formation in winter rape (Brassica napus $\mathrm{L}$. var. oleifera). Acta Agrobot. 38, 11-21.

71. Olgun M, Kumlay A M, Adiguzel M C and Caglar A 2008. Effects of waterlogging in wheat ( $T$. aestivum L.). Acta Agric. Scandinavica, (Section B). Plant Soil Sci. 58: 193-198.

72. Arbona V., Hossain Z., Climent M. F. L., Clemente R. M. P., and Cadenas A. G.(2008). Antioxidant enzymatic activity is linked to water logging stress tolerance in citrus. $\quad$ https://doi.org/10.1111/j.13993054.2007.01029.x

73. Ren B, Zhang J, Dong S, Liu P, Zhao B (2016) Effects of Waterlogging on Leaf Mesophyll Cell Ultrastructure and Photosynthetic Characteristics of Summer Maize. PLoS ONE 11(9): e0161424. doi:10.1371/journal.pone.0161424
74. Mittler, R., Suzuki, N., Koussevitzky, S., and Miller, G. (2012). ROS and redox signalling in the response of plants to abiotic stress. Plant Cell Environ., 35, 259270.

75. Lin K. H. R., Weng C. C., Lo H. F., and Chen J. T. (2004) Study of the root antioxidative system of tomatoes and eggplants under waterlogged conditions. Plant Sci 167: 355-365

76. Tang B., Xuxi S.Z., Zouyong L., Zhengfa L., Qui Z. (2010). Changes of antioxidants enzymes and lipid peroxidation in leaves and roots of water logging tolerant and waterlogging sensitive Maize genotypes at seedling stage. Agricultural Science in China.9(5):651-661 https://doi.org/10.1016/S16712927(09)60140-1

77. Chug V., Kaur N., and Gupta A.K.(2011). Role of Antioxidant and Anaerobic Metabolism Enzymes in Providing Tolerance to maize (Zea mays L.) seedlings against Water logging. Indian journal of Biochemistry and Biophysics, 48: 346-352

\section{How to cite this article:}

Debashree Dalai and Suchinnata Swapnasarita Sardar. 2021. Tolerance Response of Sunflower (Helianthus annuus L.) Cultivar NSSH-1084 to Water Logging Stress. Int.J.Curr.Microbiol.App.Sci. 10(08): 219-233. doi: https://doi.org/10.20546/ijcmas.2021.1008.026 